\title{
Formation of the Ammonium Nitrate Nanoporous Structure in the Vortex Device with Pre-humidification of Granules
}

\author{
A.E. Artyukhov, K.V. Berladir \\ Sumy State University, 2, Rymsky-Korsakov St., 40007 Sumy, Ukraine
}

(Received 10 July 2020; revised manuscript received 15 October 2020; published online 25 October 2020)

\begin{abstract}
The article deals with morphological features of the nanoporous surface of ammonium nitrate granules obtained through the humidification of the ordinary ammonium nitrate followed by heat treatment. A new method to produce porous ammonium nitrate in a vortex device with a remote pre-humidification zone is proposed. The morphology of the initial granules of the ordinary ammonium nitrate, ammonium nitrate after humidification and heat treatment in a vortex granulator, and ammonium nitrate after humidification and heat treatment in a vortex granulator with a pre-humidification zone is compared. The obtained data form the basis to improve the technology of the porous ammonium nitrate production in devices with active hydrodynamic modes.
\end{abstract}

Keywords: 3D nanostructured porous layer, Vortex granulator, Humidification, Morphology of the surface.

\section{INTRODUCTION}

Today, the existing methods to produce the porous ammonium nitrate (PAN) are being improved, and new ways are being developed [1-4].

The technological basis to obtain PAN should consider the following aspects:

- assessment of the possibility to obtain PAN without pore-forming and modifying additives;

- ensuring the strength of the granule core if there is a developed nanoporous structure of its surface and nearsurface layers;

- formation of a network of pores with required size and configuration for smooth penetration of diesel distillate into the granule and its reliable retention there; - the possibility to use granules of ordinary ammonium nitrate, but not an ammonium nitrate melt as a raw material.

These aspects are applicable for small- and medium-scale production, the privilege of which consists in the mobility of the unit and its possible operation at the blasting places. For large-scale production, it is reliable to obtain PAN in granulation towers.

The analysis of these works [5, 6] allows to propose the author's method to produce PAN granules in vortex granulators through the humidification with further heat treatment [7]. However, this method has several disadvantages that affect the uniformity of the nanoporous surface layer and the strength of the granule core: - the solution is partially removed before starting the contact with the granules - the crystallization centers (granules of the seeding agent). Consequently, it does not participate in the formation of a porous film on the granules' surface.

- the drops of the solution before entering the fluidized bed surface begin to deform due to the swirling flow of the heat transfer agent. At the time of the contact with the crystallization centers, they are heterogeneous in shape and size, which reduces the pore formation process intensity.

- the vortex flow of high-temperature heat transfer agent, which is created above the spray, promotes the swirling of the solution and its uneven distribution on the granules' fluidized bed surface.

- the drying process in the counter-vortex flow of the heat transfer agent and the pore-formation process occur simultaneously. It prevents the creation of a secure surface layer with a developed porous structure.

- the shape of the melt drop is changed from spherical to disc-shaped form due to the influence of the heat transfer agent's vortex flow on the sprayer; consequently, the inlay of the inner surface of the device was grown up.

- the granules are returned to the core of the fluidized bed by the ejection gas flow without further possibility of simultaneous drying and pore-formation due to the absence of liquid material on the granule's surface, which occurs when the granule comes into the fluidized bed surface.

- when the granule gets into the fluidized bed and before contacting with liquid material within the surface of the fluidized bed, the granule is in the flow of hightemperature heat transfer agent for more time than necessary for the drying process. It degrades its quality and prevents the formation of a granular porous structure with sufficient strength.

Thus, the humidification and heat treatment method in PAN production can have different technological and hardware designs:

- humidification and heat treatment in the workspace of one device - vortex granulator;

- humidification outside the vortex granulator and heat treatment in the vortex granulator applying a film of various solutions (multilayer PAN granules);

- heat treatment in two stages: vortex granulator and gravitational shelf dryer;

- humidification and heat treatment with various designs of devices;

- combined methods.

The scheme proposed in work [8] with a two-stage drying process has proved to be quite useful for humidification directly in a vortex granulator. The expediency in the final drying stage is significantly reduced for the PAN obtaining method with a pre-humidification zone. 
The aim of this article is to confirm the effectiveness of improving the existing method to produce PAN $[9,10]$ by creating a remote pre-humidification zone (design features of this method implementation are presented in the patent [11], a schematic diagram - in Fig. 1). The comparative studies regarding the surface morphology of various samples of PAN granules are carried out for it.

\section{DESCRIPTION OF THE OBJECT AND METHODS OF RESEARCH}

Fig. 2 demonstrates the experimental stand scheme for studying PAN granules' production process with a pre-humidification stage.

FTIR spectra were obtained by ATR technique using a Nicolet iS50 FT-IR spectrometer (by ThermoScientific) in the range from 4000 to $400 \mathrm{~cm}^{-1}$ with resolution of $4 \mathrm{~cm}^{-1}$ (no. of scans: 32 ) (sensitivity for finding the peaks was $95 \%$ ).

There are three samples for research:

- the original granules of ordinary ammonium nitrate;

- ammonium nitrate granules after humidification and heat treatment in a vortex granulator;

- ammonium nitrate granules after humidification and heat treatment in a vortex granulator with a remote pre-humidification zone.

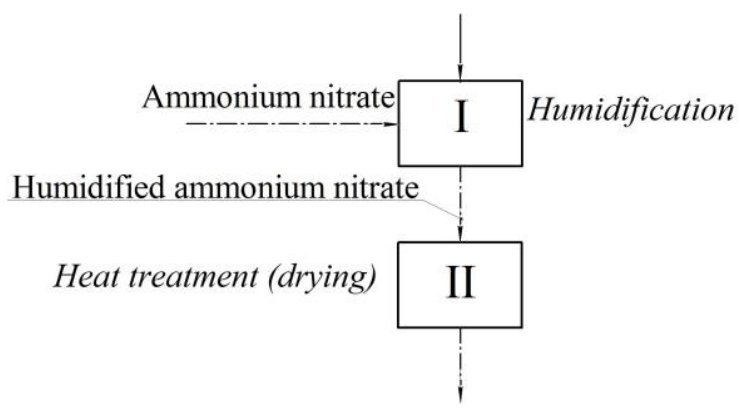

Porous ammonium nitrate

Fig. 1 - Scheme for production of PAN: I - humidification block; II - vortex granulator

\section{RESULTS AND DISCUSSION}

The initial structure of an ordinary ammonium nitrate granule is shown in Fig. 3.

The study [12] describes that "a complete surface without a developed network of pores is peculiar for the sample. The surface structure is described by "mechanical" pores in the micrometer range. These pores arose directly upon production of the granules due to temperature stresses and mechanical effect on the packed granules during their transportation from the production place. Such granules can be used as an ANFO com-

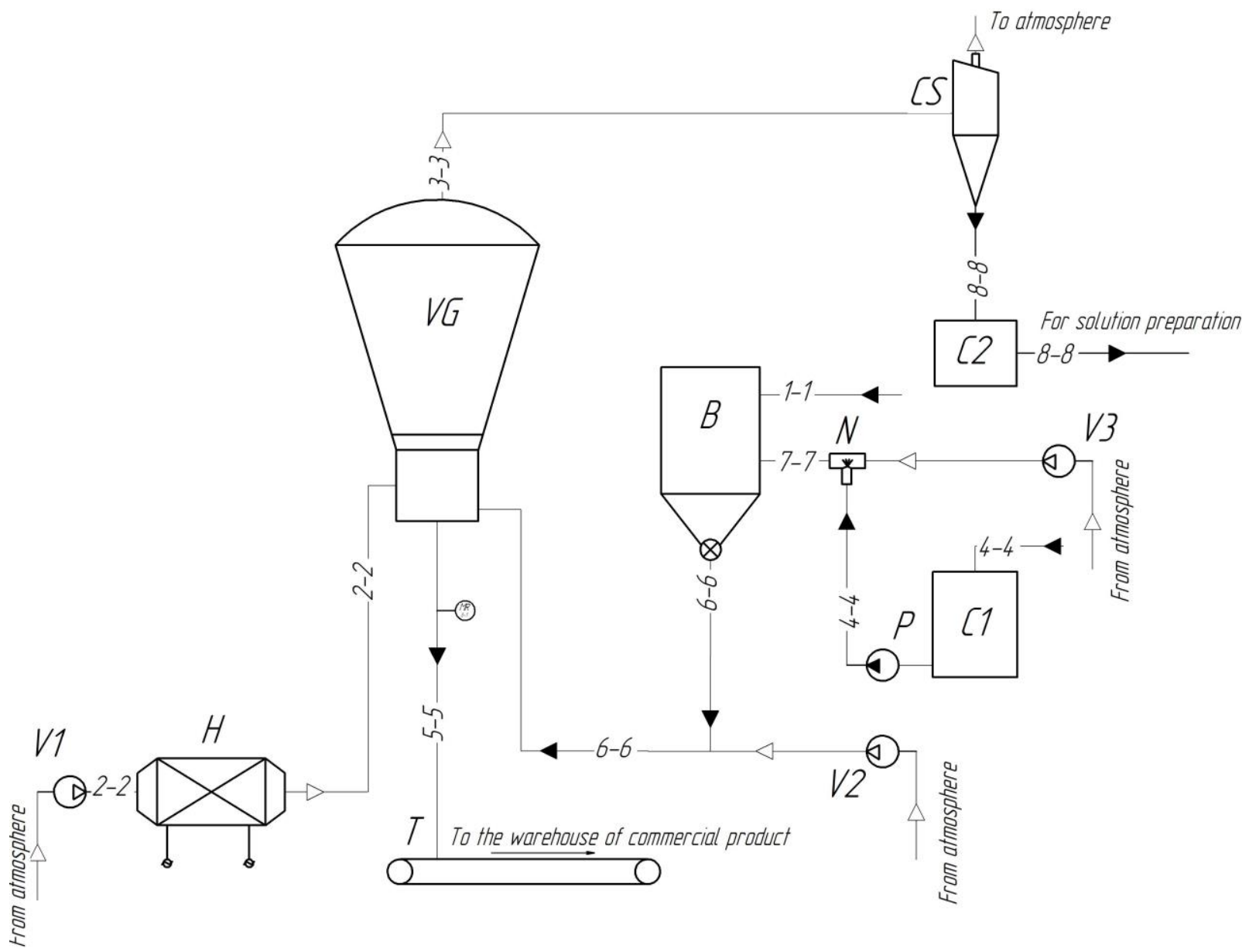

Fig. 2 - The experimental stand scheme: 1-1 - dry granules; 2-2 - technological air; 3-3 - contaminated air; 4-4 - water; 5-5 commercial product; 6-6 - moistened granules; 7-7 - moistened air; 8-8 - fine granules; VG - vortex granulator; H - hot-air heater; B - bunker; C - container; CS - cyclone separator; V - ventilator; $\mathrm{P}$ - pump; $\mathrm{N}$ - nozzle; $\mathrm{T}$ - transporter 
ponent without prior preparation. The absorptivity of the sample is quite high due to large "mechanical" pores. The retentivity of the sample does not meet the standard indicator. The reason is that the diesel distillate easily leaves the granule (it flows from faults on its surface influenced by the gravity)".

A PAN granule sample after humidification and heat treatment in the workspace of the vortex granulator is shown in Fig. 4.

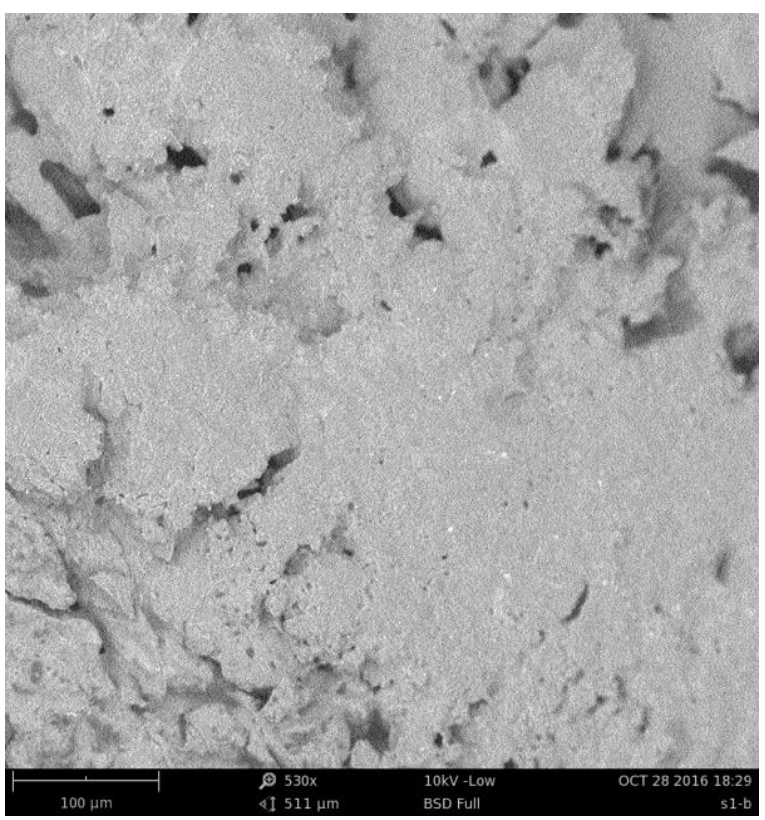

Fig. 3 - The initial structure of an ordinary ammonium nitrate granule

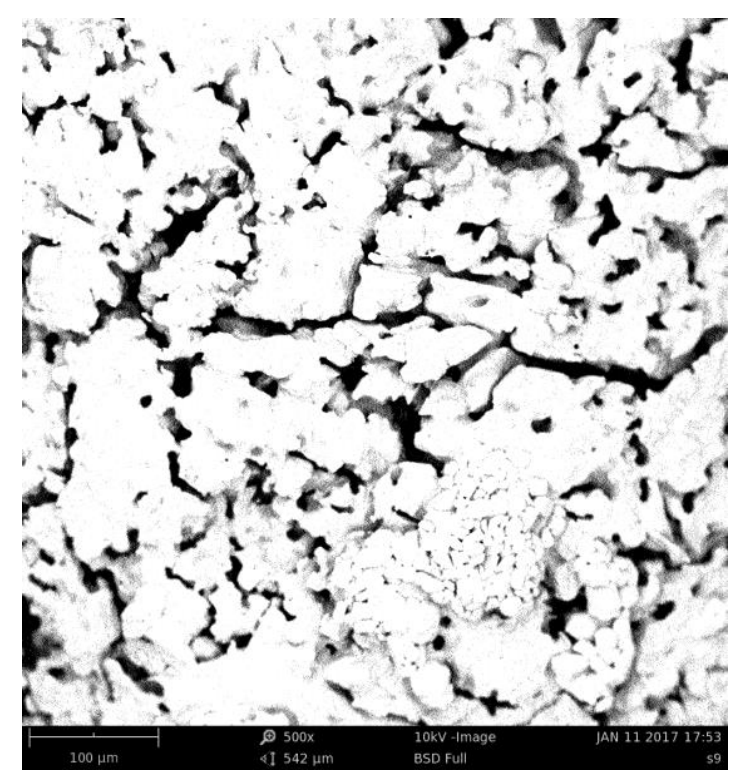

Fig. 4 - PAN granule structure after humidification and heat treatment in the vortex granulator's workspace

The observed sample is characterized by a developed network of nanopores, which contributes to an increase in the granule's absorptivity and retentivity to the diesel fuel distillate. However, the surface morphology analysis showed that along with the nanopores network, the sample is characterized by the formation of new "mechanical" pores in the micrometer range due to excessive temperature stresses and significant mutual action of granules in a vortex flow. "Mechanical" pores reduce the strength of the granule and do not allow long-term transportation. Such pores are generally not critical for obtaining effective ANFO without its subsequent longterm storage and long-distance transportation.

A PAN granule after humidification and heat treatment in a vortex granulator with a remote prehumidification zone is shown in Fig. 5.

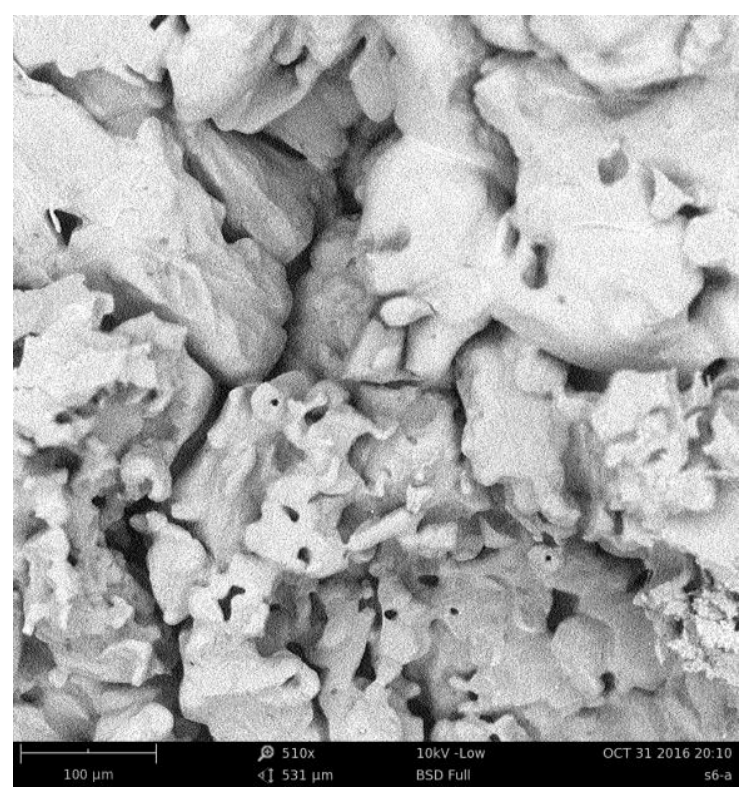

Fig. 5 - Structure of a PAN granule after humidification and heat treatment in a vortex granulator with a remote prehumidification zone

Although the sample also has a developed network of nanopores, it differs from the previous one:

- nanopores are deeper and more swirling. It allows to predict a higher retentivity to diesel distillate;

- fewer "mechanical" pores, which enable to maintain the strength of the granule and ensure the possibility of transportation to the blasting place;

- high proportion of porous surface concerning the total surface of the granule.

The authors additionally study the elemental (see Fig. 6a) and phase (Fig. 6b) compositions of the granule after humidification and heat treatment for this sample. Analysis of the elemental composition shows a high concentration of oxygen in the granule, which increases the detonation ability of the granule. The study of the phase composition demonstrates the coincidence of the peaks corresponding to the ammonium nitrate card; therefore, the intensity of the peaks and their location are slightly shifted. It occurs due to the residual moisture in the PAN granule. 


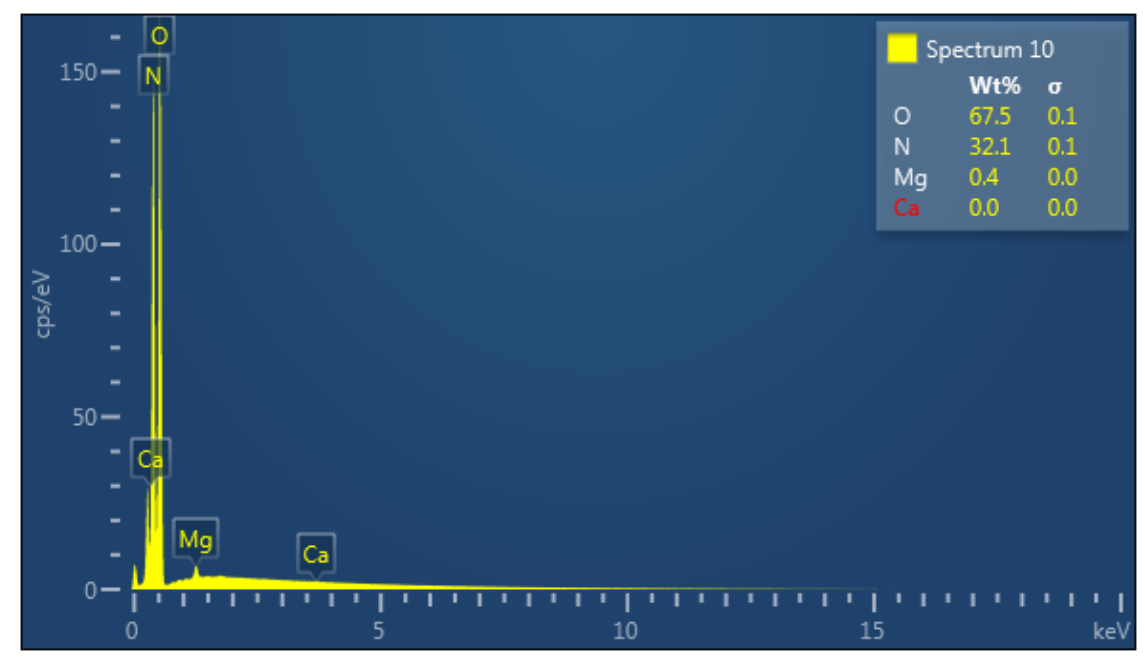

a

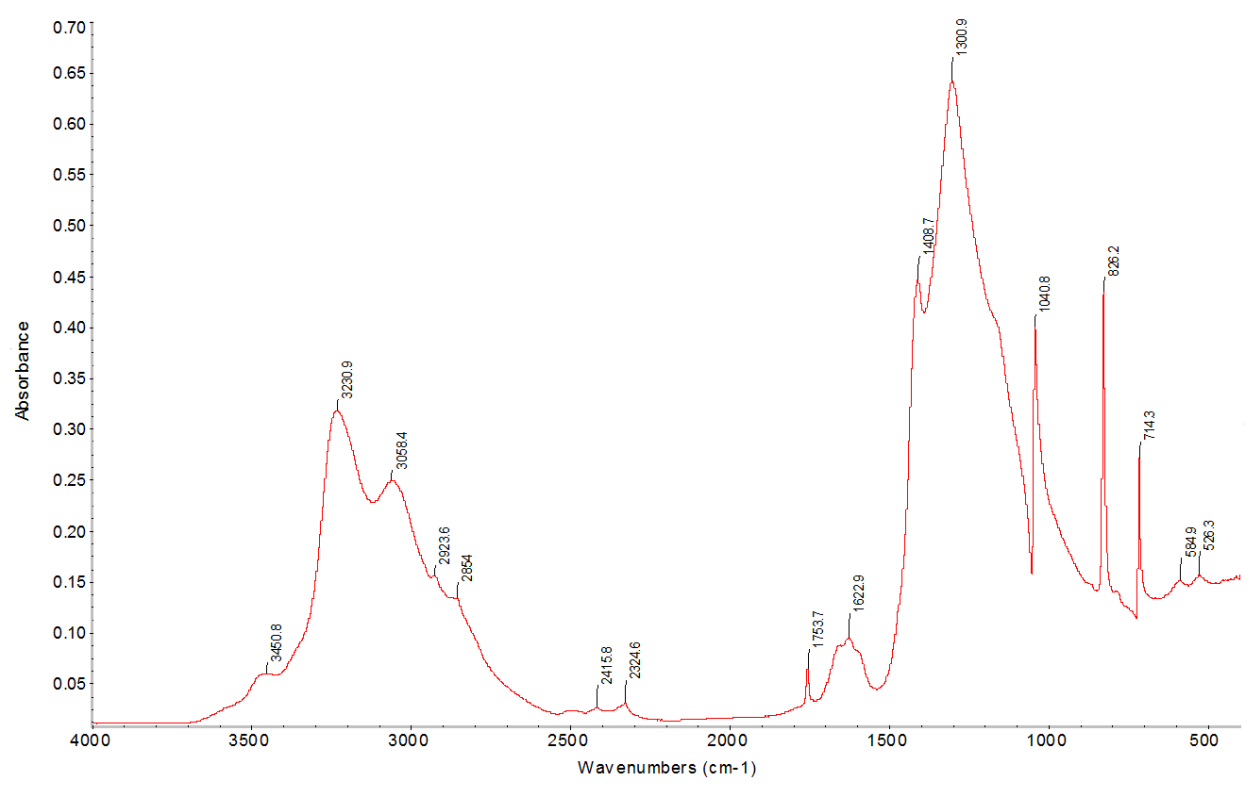

$\mathrm{b}$

Fig. 6 - Elemental (a) and phase (b) compositions of the granule after humidification and heat treatment in a vortex granulator with a remote pre-humidification zone

\section{CONCLUSIONS AND RECOMMENDATIONS}

Humidification of the granule with liquid by the above method allows to create a developed porous structure on its surface within the core of the fluidized bed at the initial stage of contact with the vortex flow of high-temperature heat transfer agent before the granule comes to the fluidized bed surface. It also prevents the formation of various granules except spherical ones and eliminates the influence on the spraying process of the uneven flow of liquid material to the sprayer. Besides, the probability of contamination of the inner cone walls is reduced. The possibility of collision of the liquid material drops due to the lack of spraying process in the workspace is eliminated. It increases the monodispersion degree of the granulometric composition of the final product, homogeneity in mass and strength indicators and developed porous film on the granule surface.

The drying uniformity of liquid material on the surface of the granule and homogeneity of the porous surface structure formed during the drying process in the high-temperature vortex flow of the heat transfer agent is also achieved by reducing the influence of the counter vortex axisymmetric flow of the heat transfer agent and uniform distribution of wet granules in the fluidized bed.

The obtained uniform layer of liquid material on the surface of the granule during its pre-humidification enables to implement the uniformity principle. It means that in the pore-formation process it is necessary to achieve forces with the same activity arising from the interaction of humidified granules and vortex axisymmetric flow per each granule. 


\section{- 1 "modified" pores \\ = 2 "mechanical" pores}

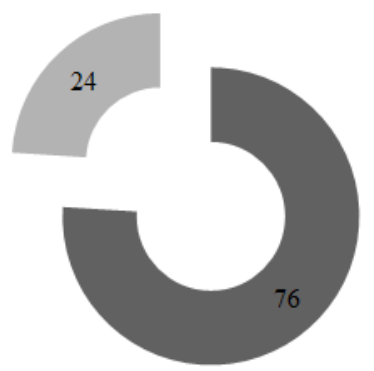

a

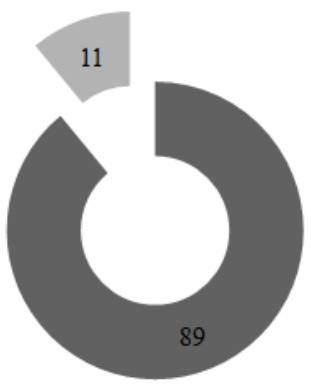

b
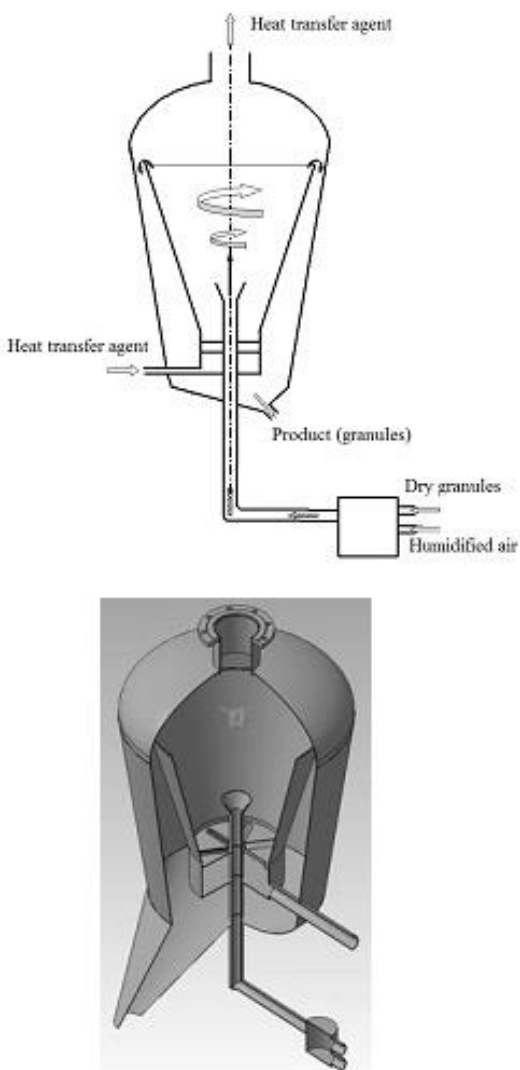

in PAN samples: a - after humidification and heat treatment in the vortex granulator; b - after humidification and heat treatment in the vortex granulator with a remote prehumidification zone

$\square 1$ porous area

2 non-porous area

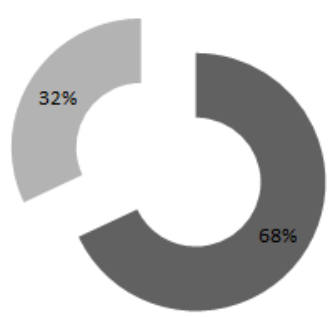

a

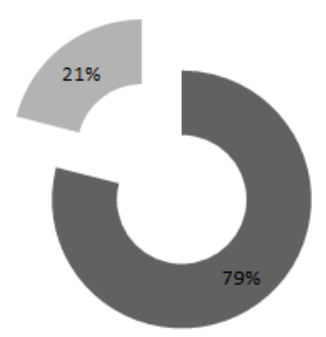

b

Fig. 8-Relative area of porous surface in PAN samples: a - after humidification and heat treatment in the vortex granulator; $b$ - after humidification and heat treatment in the vortex granulator with a remote pre-humidification zone

a

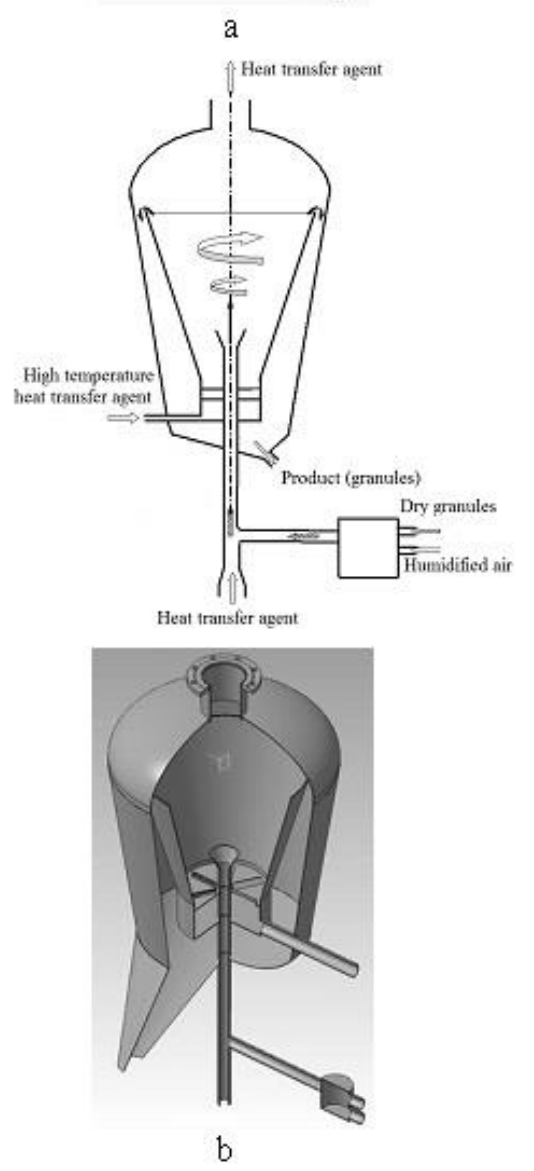

Fig. 9-Vortex granulators with a remote humidification zone: a - without pre-heating of granules; $b$ - with pre-heating of granules 

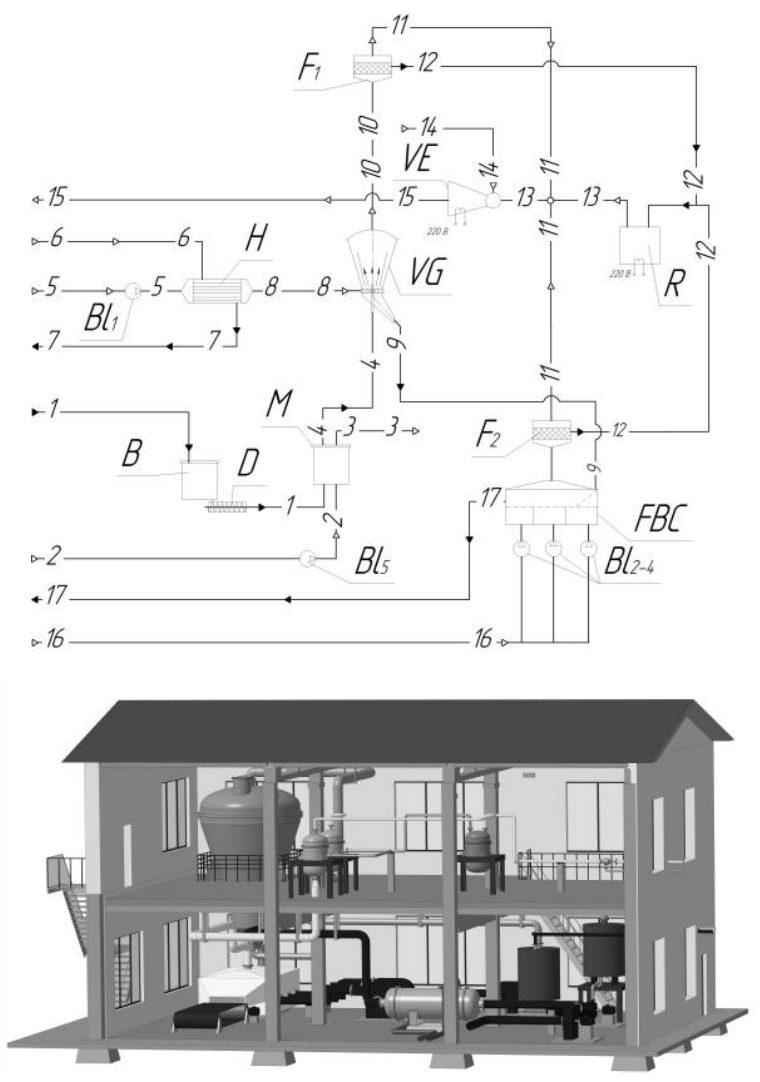

Fig. 10 - The scheme of the industrial unit: 1-1 - ammonium nitrate granules; 2-2 - contaminated air; 3-3 - dry air; 4-4 moistened ammonium nitrate granules; 5-5 - cold air; 6-6 steam; 7-7 - water; 8-8 - hot air; 9-9 - porous ammonium nitrate; 10-10 - dusty gas-air mixture; 11-11 - gas-air mixture; 12-12 - dust and fine fraction of ammonium nitrate; 13 13 - nitric oxide (I); 14-14 - oxygen; 15-15 - nitric oxide (II); 16-16 - cold air; $17-17$ - porous ammonium nitrate for package; VG - vortex granulator; $\mathrm{H}$ - heater; $\mathrm{B}$ - bunker; $\mathrm{Bl}$ blower; FBC - fluidized bed cooler; F - filter; D - dispenser; R - reactor; VE - vortex ejector; $\mathrm{M}$ - moisturizer

When installing an element for granules humidification in the device before entering the workspace thanks to the latter, conditions are created for uniform application of liquid material on the surface of granules without destabilizing factors: impact on the granule and liquid material film of the counter vortex flow of heat transfer agent, possibility of collision and agglomeration of separate drops, time non-uniformity of the contact between the humidified material and the hightemperature heat transfer agent, entry of the granule to a fluidized bed zone where there is no possibility of humidification by liquid material. Besides, for all mois-

\section{REFERENCES}

1. D. Buczkowski, Cent. Eur. J. Energ. Mat. 8 No 2, 99 (2011).

2. Ammonium Nitrate Explosives for Civil Applications: Slurries, Emulsions and Ammonium Nitrate Fuel Oils (Ed. G.M. Erode) (Weinheim: Wiley-VCH Verlag \& Co: 2013).

3. G. Martin, W. Barbour, Industrial nitrogen compounds and explosives (Watchmaker Publishing: 2003).

4. S.S. Verma, Chemical Business, 22 No 12, 33 (2008).

5. A.V. Starshinov, S.S. Kostylev, I.Yu. Kupriyanov, J. Zhamyan, R.A. Gilmanov, Burovzryunyye Raboty 5 No 135, 69 (2017) (in Russian). tened granules, the time interval of contact with the flow of high-temperature heat transfer agent is balanced and minimized.

The proposed method to obtain porous granules and device for its implementation will increase the efficiency of heat and mass transfer processes and pore formation on the surface of granules, their uniformity, and increase the fraction of granules with a uniform porous layer of dried liquid material in a given range of sizes and weights. It increases the monodispersity of the particle size distribution of the material and improves the final product quality.

The studies of the PAN morphology showed that pre-humidification outside the vortex granulator allows to reduce the number of "mechanical" pores that have arisen as a result of overheating of the granule and its long-term stay in a vortex two-phase flow (Fig. 7) and to increase the relative porous surface area (Fig. 8).

The proposed method is implemented in a vortex granulator and a unit, varieties of which are shown in Fig. 9. The granulator operates as a part of the unit shown in Fig. 10.

A vortex fluidized bed of granules is created in the additional case of the granulator. A heat transfer agent's stream with an operating temperature of 95$105^{\circ} \mathrm{C}$ and a flow rate of $15000 \mathrm{~m}^{3} / \mathrm{h}$ or $4 \mathrm{~m} / \mathrm{s}$ on the free plane of a smaller cross-section of the additional open cone of the device is brought to the granulator under the swirler. Humidified granules with a flow rate of $1500 \mathrm{~kg} / \mathrm{h}$ are introduced into the vortex granulator's workspace, into the inner cone, pneumatically, influenced by pneumatic carrier, which uses air with a humidity of $100 \%$. The granules are humidified in the humidification element to a humidity of 0.15-0.2\%.

Due to the pre-humidification of granules, the uniformity of the porous layer on the granule surface and the monodispersity degree increase. By reducing the contact time with the high-temperature flow of the heat transfer agent, the strength of the granule is maintained in a given range. The commodity fraction granules preferably have a size of $3 \times 0.3 \mathrm{~mm}$, which is $90 \%$ of their content in the finished product. The strength of the finished product is $400-450 \mathrm{~g} / \mathrm{granule}$, the retentivity of the granules is $9-9.5 \%$, the friability of the granules is $100 \%$.

\section{ACKNOWLEDGEMENTS}

This work was carried out under the project "Technological bases of multistage convective drying in smallsized devices with utilization and heat recovery units", project No. $0120 \mathrm{U} 100476$.
6. S.D. Viktorov, A.E. Frantov, I.N. Lapikov, V.V. Andreev, A.V. Starshinov, Combustion, Explosion and Shock Waves 52 No 6,727 (2016).

7. A. Artyukhov, A. Ivaniia N. Artyukhova, J.Gabrusenoks, IEEE International Young Scientists Forum on Applied Physics and Engineering (YSF 2017), 315 (2017).

8. N. Artyukhova, J. Krmela, J. Nano- Electron Phys. 11 No 4, 04006 (2019).

9. A. Artyukhov, N. Artyukhova, J. Environ. Health Sci. Eng. 16 No 2, 193 (2018). 
10. A.E. Artyukhov, V.I. Sklabinskyi, J. Nano- Electron Phys. 9 No 1, 01015 (2017).
11. Pat. No. 93649 UA Device for obtaining of granules with porous structure (2016).

12. N. Artyukhova, J. Nano- Electron Phys. 12 No 4, 04036 (2020).

\title{
Формування нанопористої структури аміачної селітри в вихрових апаратах з попереднім зволоженням гранул
}

\author{
А.Є. Артюхов, Х.В. Берладір
}

Сулський державний університет, вул. Римського-Корсакова, 2, 40007 Суми, Украйна

Стаття присвячена вивченню морфологічних особливостей нанопористої структури поверхні гранул аміачної селітри, які отримані методом зволоження рядової аміачної селітри з наступною їі термообробкою. Запропоновано новий спосіб отримання пористої аміачної селітри в вихрових апаратах з винесеною зоною попереднього зволоження. Представлена порівняльна характеристика морфології вихідних гранул рядової аміачної селітри, аміачної селітри після зволоження і термообробки в вихровому грануляторі, аміачної селітри після зволоження і термообробки в вихровому грануляторі з винесеною зоною попереднього зволоження. Отримані дані є основою для удосконалення технології отримання пористої аміачної селітри в апаратах з активними гідродинамічними режимами.

Ключові слова: 3D наноструктурований пористий шар, Вихровий гранулятор, Зволоження, Морфологія поверхні. 